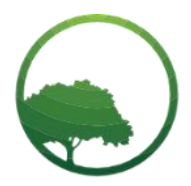

Research in Business \& Social Science

IJRBS VOL 10 NO 7 ISSN: 2147-4478

Business \& Social Science IJRBS

\title{
Gamification as a marketing strategy for Garuda Indonesia loyalty program
}

(D) Donafeby Widyani

${ }^{(a)}$ Student, Macquarie Business School, Macquarie University, Balaclava Road, North Ryde, NSW, 2109. Australia. Postal address: Macquarie University, NSW, 2109, Australia

\author{
ARTICLE INFO \\ Article history: \\ Received 02 October 2021 \\ Received in rev. form 27 Oct. 2021 \\ Accepted 04 November 2021 \\ Keywords: \\ Gamification, Garuda Indonesia, \\ Loyalty Program, Marketing \\ JEL Classification: \\ M310
}

\begin{abstract}
A B S T R A C T
This paper addresses issues about how gamification can provide a breakthrough marketing strategy for Garuda Indonesia Loyalty Program. Garuda Indonesia is a well-known national airline in Indonesia. However, the survey found that the Garuda Indonesia loyalty program and does not attractive enough for consumers. Garuda Indonesia should maintain its loyalty program to attract more consumers. Moreover, the frequent flyer program is one way to differentiate the products offered by an airline from other competitors. Answering that phenomenon, Garuda Indonesia launched a mobile application that has several offers for consumers. However, Consumers still tend to choose other mobile applications. Garuda Indonesia's marketer should encourage consumers to use the mobile application with the loyalty program inside the mobile application. Study suggests that Garuda Indonesia can add the gamification concept to the Garuda Indonesia Mobile application to increase loyalty to GarudaMiles users.
\end{abstract}

(C) 2021 by the authors. Licensee SSBFNET, Istanbul, Turkey. This article is an open access article distributed under the terms and conditions of the Creative Commons Attribution (CC BY) license (http://creativecommons.org/licenses/by/4.0/).

\section{Introduction}

In this digital age, companies are increasingly competing for market share (Gatautis et al, 2016). Many businesses use innovative marketing techniques to promote their goods (Zatwarnicka, 2014). To attract the market, it is recommended that a good marketing strategy be developed, and marketing should be innovative (Yang, Asaad \& Dwivedi, 2019). A marketing strategy is a concept that entails selecting a specific market as the company's target market and developing the appropriate mix of product or service, promotion, price, and distribution system to meet the needs of the customer (Burns \& Veeck, 2017). To attract customers, businesses can use a variety of new marketing strategies.

The gamification method in the brand mobile application is one of them. Gamification is an effective method for increasing consumer engagement (Zichermann \& Cunningham, 2011).

In marketing, gamification refers to when a company incorporates game elements into their marketing programs, such as a brand mobile application or a loyalty program. Gamification also refers to the application of game elements to non-game situations (Seaborn \& Fels, 2015). To put it another way, gamification is a method of thinking in a game context to engage players in the activity (Zichermann \& Cunningham, 2011). Furthermore, gamification does not imply the creation of games, but rather the enhancement of the user experience of a brand's mobile application and the creation of a desire for participation without jeopardizing the marketing's credibility (Muntean, 2011).

Gamification has evolved over time, it started from research in 2011 by Deterding et al and reached its top waves in 2013 (Mora et al, 2015). and according to a recent study, gamification methods in marketing encourage consumers to choose a brand and make users feel comfortable. (Lu \& Ho, 2020). According to other studies, gamification has the ability to alter human behavior (Landers et al, 2018). Consumer engagement, brand loyalty, and brand awareness are the main goals of gamified marketing (Lu \& Ho, 2020).

* Corresponding author. ORCID ID: 0000-0001-8670-4567

(C) 2021 by the authors. Hosting by SSBFNET. Peer review under responsibility of Center for Strategic Studies in Business and Finance.

https://doi.org/10.20525/ijrbs.v10i7.1405 
This study describes the marketing strategy to improve Garuda Indonesia's loyalty program. This study used qualitative or content document analysis, Meta-Analysis is research from main data that performs systematic and empirical descriptive data. This study aims to investigate the marketing strategy to improve Garuda Indonesia's loyalty program qualitatively. In this study, researchers collected documents as data to be processed from journals and articles. This data collection focuses on research journals, books, newspapers, and articles. The collected data was then sorted based on the year of publication.

\section{Gamification and Marketing}

To make gameplay more enjoyable, gamification employs several game mechanics such as a leaderboard, rewards, points, and a progress bar (Hamamari, Koivisto, \& Sarsa, 2014). Players can see their order on the leaderboard, which is called a ranking, based on their score. Discounts and vouchers can be used as rewards (Zichermann \& Cunningham, 2011). On the mobile brand application, players can exchange points for real-world items such as goods. The progress bar displays information about how close they are to completing the game's goal (Zichermann \& Cunningham, 2011). Players can be prompted to complete existing missions by the progress bar (Zichermann \& Cunningham, 2011). There will be an increase in the brand stickiness of buyers if gamified marketing is implemented with a leader board, rewards, points, and progress bars (Lu \& Ho, 2020).

Gamification is related to other theories such as marketing co-creation. Value co-creation is the transaction that takes place in which the consumer and the producer collaborate for the best total value through product features, delivery terms, maintenance, and financing options (Sheth and Uslay, 2007). Value co-creation will inevitably transform marketing and become just as pervasive in the business consumer market as it is in business-to-business marketing (Sheth and Uslay, 2007). Gamification and marketing cocreation share a sense of engagement and immersion (Thorpe \& Roper, 2019).

\section{Value Creation Process Gamification Process}

The similarity of gamification and marketing co-creation is, in Gamification, the player is part of the co-production (Houtari \& Hamamari, 2017). The value creation process in gamification appears every time the game is played and interacted (Houtari \& Hamamari, 2017). Gamification like marketing co-creation also can promote consumer participation in brand co-creation experiences because it requires voluntary participation (Nobre \& Ferreira, 2017).

The difference between gamification and marketing co-creation, gamification is more powerful to motivate engagement because gamification has manipulation game experience and marketing co-creation does not have it (Thorpe \& Roper, 2019). From a value co-creation perspective, the value is considered created just in the production process and the value is transferred to the consumer through the hand of the product unlike the gamification (Houtari \& Hamamari, 2017).

There are contemporary marketing issues that can be addressed with gamification concepts which are in the airline industry. In airline business services, many factors cause flight ticket prices to fluctuate and make it difficult for seats to attract customers to continue to buy airline tickets from them. One of the factors is the increase in aviation fuel costs on planes. To work around this, every airline service company needs to continuously make improvements in every sector of its business. To increase passenger loyalty, several airlines already have Frequent Flyer Programs.

\section{Gamification in Aviation}

Several foreign airlines have launched platforms for frequent flyer programs. For example Delta Airlines and Air Canada. Delta Airlines created a simple platform called Delta Airlines Mileages Comparison Calculator. Furthermore, Air Canada airline has a platform called Earn Your Wings with a gamification concept. To increase passenger loyalty, Garuda Indonesia also already has a Frequent Flyer Program. The frequent flyer program is one way to differentiate the products offered by an airline from other competing airlines. The frequent flyer program offered by Garuda Indonesia is called Garuda Miles. Garuda Miles is a program that Garuda Indonesia offers to its loyal customers in the form of points that can be exchanged for plane tickets and other privileges (garuda-indonesia.com, 2018).

The frequent flyer program is one way to differentiate the products offered by an airline from other competitors. At the most basic membership tier, flight distance contributes to future profits through distance or points accumulated. At higher membership tiers, the greater the benefit is an upgrade to the baggage service or seats. These advantages will attract consumers to make continuous purchases (Conaway \& Garay, 2014).

Accenture's analysis of global airplane user data shows that almost a portion of frequent flyer program users still transacts no more than once during a three-year period (Accenture, 2016). In fact, research by Seelhorst \& Liu (2015) states that frequent flyer program users, specifically users who have reached the membership stage, have a strong tendency to choose travel plans. In addition, 72 percent of high-frequency business players participate in two or more airline loyalty programs (Deloitte, 2013). This indicates that even though a loyalty program is available, airlines need to keep passengers from moving to other, more attractive loyalty programs.

In a study by KPMG (2019) globally, more than six consumers agree that a strict loyalty program to follow or existing rewards are difficult to obtain. The long registration process, the regulations that are sometimes clear and changing, and the technical difficulties when cashing out rewards make it difficult for consumers to access the loyalty program offered by the company (KPMG, 2019). Therefore, it is necessary to have something that can increase members to become more active users. 
We can apply gamification theories to address several issues. Gamification can be applied in the loyalty program of airplanes (Huotari \& Hamamari, 2012). Garuda Indonesia also has an application called Garuda Indonesia Mobile. On the Garuda Indonesia Mobile application, passengers can make ticket bookings, view flight schedules, view the number of Garuda Miles points, and so on. However, Ramadhan et al research (2018) states that the mobile application from Garuda Indonesia does not show any advantages over other similar applications. It can be seen from the aspect of user interface interest, this application is considered to be less motivating for users to use it regularly in terms of content and design. From this study, it was also found that customers did not get significant value, trust, interest, and usefulness from the Garuda Indonesia mobile apps (Ramadhan, 2018). A product is needed that can bind passengers to Garuda Indonesia itself. Therefore, the author suggests that Garuda Indonesia can add the gamification concept to the Garuda Indonesia Mobile application to increase loyalty to GarudaMiles users.

In 2018, the amount of Mileage Redeem was recorded at 4,871.05 million, a significant increase of $135.77 \%$ compared to 2017 which amounted to 2,065.99 million. This increase is in line with the increase in the number of GAMiles Members by $99.39 \%$ in 2018 (Garuda Indonesia Annual Report, 2018). The application of the gamification concept is needed to answer this extraordinary enthusiasm. In addition, gamification is deemed necessary in order to increase passive members to transact more frequently. From the explanation above, the desired behavior to appear through the use of gamification on the GarudaMiles page on the Garuda Indonesia Mobile application is that application users know the points of miles each month through my points feature, application users can find out various ways to earn points through the feature. find points, application users get information regarding the terms and conditions of Garuda Miles through the bulletin feature, application users can consult online with customer service or BOT through the consultation feature.

\section{Conclusion}

There are strengths of gamification in marketing to address the issue, which are increased profit and brand engagement. For starters, gamification increases customer brand engagement. Gamification motivates users to learn about a brand because positive feedback from the system can entice customers to use the brand's mobile app (Muntean, 2011). Furthermore, gamification methods will make using the mobile app for payment more enjoyable. In mobile devices, marketers can attract consumers anywhere and anytime (Arshad, 2017). The companies' profits will increase as a result of the second benefit. Gamification can turn a consumer's experience into a game in order to boost product sales in a brand's mobile app (Zichermann \& Cunningham, 2011). Consumer buying behavior will increase in frequency, duration, speed, and intensity when using the gamification method (Miltenberger, 2012). Customers will tend to buy more and eventually increase the company's profit if customer motivation to do activities in the brand mobile application increases. Gamification also encourages customers through entertainment and makes a good deal of value for the business (Hsu \& Chen, 2018).

Despite the strengths, there are limitations of gamification in marketing to address the issue. The limitation is the high cost of development (Seaborn \& Fels, 2015). It is because the company should provide a budget for brand application development and for hire expert consultants (Bogost, 2014). The company also needs new departments and hires much new staff for increasing technological aspects because the development of gamification is difficult (Robson et al, 2014). Technological aspects include IT infrastructure such as the software and internet (Kreutzer, 2018). Another limitation is gamification methods can bring addiction (Hyrynsalmi et al, 2017). Gamification leads to compulsive behavior (Eisingerich et al, 2019).

Gamification addiction can cause negative effects for users such as sleep deprivation and social isolation (Ndi, 2018). Gamification also allows businesses to take the personal information of customers and in exchange give benefits such as discounts (Hwang \& Choi, 2020). This will harm consumer privacy about their personal data (Mavroeidi et al, 2019). Gamification is also still in its infancy stage and still a new concept in marketing (Hamid \& Kuppusamy, 2017). Marketers also need constant novelty such as new joy and surprises in their gamification method to prevent customer boredness and it is difficult to maintain (Lee \& Jin, 2019).

For managerial implication, further benefits of gamification are establishing a database of Garuda Indonesia customers itself, Garuda Indonesia can see the consumption patterns of Garuda Indonesia customers themselves. So that this can later be used as a tool in determining further marketing planning. Gamification also can keep users active using the Garuda Indonesia airline by adding a notification feature that serves to remind customers at certain times. It also can provide important information such as promotions and discounts specifically for GarudaMiles users in real-time. Garuda Miles is not only a membership card but the miles in it are also a medium of exchange that can be exchanged at merchants that cooperate with Garuda Miles. This product is one way for Garuda to collaborate with other companies, and can even serve as a means of information as a marketing strategy in the future.

One perspective that needs to be considered is gamification can be beneficial if it is monitored and controlled by the company (Adrade, 2016). Companies also need to think about social responsibility and ethics for the use of gamification in marketing (Thorpe \& Roper, 2019).

This study finally suggests that Garuda Indonesia can add the gamification concept to the Garuda Indonesia Mobile application to increase loyalty to GarudaMiles users. 


\section{References}

Accenture (2016). Make Your Digital Connection: From Digital Strategy to Airline Strategy. Retrieved from https://www.accenture.com/_acnmedia/pdf-16/accenture-make-your-digital-connection-from-digital-strategy-to-airlinestrategy pada (April 19, 2021)

Andrade, F. R., Mizoguchi, R., \& Isotani, S. (2016, June). The bright and dark sides of gamification. In International conference on intelligent tutoring systems (pp. 176-186). Springer, Cham.

Annual Report Garuda Indonesia (2018). Garuda Indonesia Annual Report. Jakarta : Garuda Indonesia

Arshad, P. M. A. E. P., \& Baharun, R. (2017). A conceptual framework review of gamification elements on mobile marketing outcomes. Advanced Science Letters, 23(9), 8362-8367.

Bogost, I. (2014). Why gamification is bullshit. The gameful world: Approaches, issues, applications, 65-80.

Conaway, R., \& Garay, M. C. (2014). Gamification and service marketing. SpringerPlus, 3(1), 1-11.

Deloitte (2013). Charting a course for renewed airline loyalty. Retrieved from https://www2.deloitte.com/tr/en/pages/consumerbusiness/articles/rising-above-the-clouds-aviation-transportation-loyalty.html (April 19, 2021)

Eisingerich, A. B., Marchand, A., Fritze, M. P., \& Dong, L. (2019). Hook vs. hope: How to enhance customer engagement through gamification. International Journal of Research in Marketing, 36(2), 200-215.

Garuda-indonesia.com (2018). Tentang Garuda Miles. Retrieved from https://www.garuda-indonesia.com/garudamiles/id/tentanggarudamiles/index.page (April 19, 2021)

Gatautis, R., Banyte, J., Piligrimiene, Z., Vitkauskaite, E., \& Tarute, A. (2016). The impact of gamification on consumer brand engagement. Transformations in Business \& Economics, 15(1).

Hamari, J., Koivisto, J., \& Sarsa, H. (2014, January). Does gamification work?--a literature review of empirical studies on gamification. In 2014 47th Hawaii international conference on system sciences (pp. 3025-3034). Ieee.

Hamid, M., \& Kuppusamy, M. (2017). Gamification implementation in service marketing: literature. Electronic Journal of Business \& Management, 2(1), 38-50.

Hsu, C. L., \& Chen, M. C. (2018). How does gamification improve user experience? An empirical investigation on the antecedents and consequences of user experience and its mediating role. Technological Forecasting and Social Change, 132, 118-129.

Huotari, K., \& Hamari, J. (2012, October). Defining gamification: a service marketing perspective. In Proceeding of the 16th international academic MindTrek conference (pp. 17-22).

Huotari, K., \& Hamari, J. (2017). A definition for gamification: anchoring gamification in the service marketing literature. Electronic Markets, 27(1), 21-31.

Hwang, J., \& Choi, L. (2020). Having fun while receiving rewards?: Exploration of gamification in loyalty programs for consumer loyalty. Journal of Business Research, 106, 365-376.

Hyrynsalmi, S., Smed, J., \& Kimppa, K. (2017, May). The Dark Side of Gamification: How We Should Stop Worrying and Study also the Negative Impacts of Bringing Game Design Elements to Everywhere. In GamiFIN (pp. 96-104).

KPMG (2019). The truth about customer loyalty. Retrieved from https://assets.kpmg/content/dam/kpmg/ar/pdf/the-truth-aboutcustomer-loyalty (April 19 2021)

Kreutzer, R. T. (2019). Toolbox for Marketing and Management: Creative Concepts, Forecasting Methods, and Analytical Instruments. Springer.

Landers, R. N., Auer, E. M., Collmus, A. B., \& Armstrong, M. B. (2018). Gamification science, its history, and future: Definitions and a research agenda. Simulation \& Gaming, 49(3), 315-337.

Lee, J. Y., \& Jin, C. H. (2019). The role of gamification in brand app experience: The moderating effects of the 4Rs of app marketing. Cogent Psychology, 6(1), 1576388.

Lu, H. P., \& Ho, H. C. (2020). Exploring the impact of gamification on users' engagement for sustainable development: A case study in brand applications. Sustainability, 12(10), 4169.

Mavroeidi, A. G., Kitsiou, A., Kalloniatis, C., \& Gritzalis, S. (2019). Gamification vs. privacy: Identifying and analyzing the major concerns. Future Internet, 11(3), 67.

Miltenberger, R. G. (2015). Behavior modification: Principles and procedures. Cengage Learning.

Mora, A., Riera, D., Gonzalez, C., \& Arnedo-Moreno, J. (2015, September). A literature review of gamification design frameworks. In 2015 7th International Conference on Games and Virtual Worlds for Serious Applications (VS-Games) (pp. 1-8). IEEE.

Muntean, C. I. (2011, October). Raising engagement in e-learning through gamification. In Proc. 6th international conference on virtual learning ICVL (Vol. 1, pp. 323-329).

Ndi, A. (2018). Digital marketing gamification and limitations of its strategic power: exploring the online universe of the consumer in critical contexts of political economy. Greener Journal of internet, information, and communication systems, 4(1), pp.2029.

Nobre, H., \& Ferreira, A. (2017). Gamification as a platform for brand co-creation experiences. Journal of Brand Management, 24(4), 349-361.

Ramadhan, S., Purwandari, B., Sandhyaduhita, P. I., Kumaralalita, L., \& Ansori, M. S. Z. (2018, October). Factor analysis of intention to use Garuda Indonesia mobile application. In 2018 International Conference on Advanced Computer Science and Information Systems (ICACSIS) (pp. 157-162). IEEE. 
Robson, K., Plangger, K., Kietzmann, J., McCarthy, I., \& Pitt, L. (2014). Understanding gamification of consumer experiences. ACR North American Advances.

Seaborn, K., \& Fels, D. I. (2015). Gamification in theory and action: A survey. International Journal of human-computer studies, 74, 14-31.

Seelhorst, M., \& Liu, Y. (2015). Latent air travel preferences: Understanding the role of frequent flyer programs on itinerary choice. Transportation Research Part A: Policy and Practice, 80, 49-61.

Sheth, J. N., \& Uslay, C. (2007). Implications of the revised definition of marketing: from exchange to value creation. Journal of Public Policy \& Marketing, 26(2), 302-307.

Thorpe, A. S., \& Roper, S. (2019). The ethics of gamification in a marketing context. Journal of business ethics, 155(2), $597-609$.

Yang, Y., Asaad, Y., \& Dwivedi, Y. (2017). Examining the impact of gamification on the intention of engagement and brand attitude in the marketing context. Computers in Human Behavior, 73, 459-469.

Zatwarnicka-Madura, B. (2015). Gamification as a Tool for Influencing Customers' Behaviour. International Journal of Economics and Management Engineering, 9(5), 1461-1464.

Zichermann, G., \& Cunningham, C. (2011). Gamification by design: Implementing game mechanics in web and mobile apps. " O'Reilly Media, Inc.".

Publisher's Note: SSBFNET stays neutral with regard to jurisdictional claims in published maps and institutional affiliations.

\section{(9) (1)}

(C) 2021 by the authors. Licensee SSBFNET, Istanbul, Turkey. This article is an open access article distributed under the terms and conditions of the Creative Commons Attribution (CC BY) license (http://creativecommons.org/licenses/by/4.0/).

International Journal of Research in Business and Social Science (2147-4478) by SSBFNET is licensed under a Creative Commons Attribution 4.0 International License. 